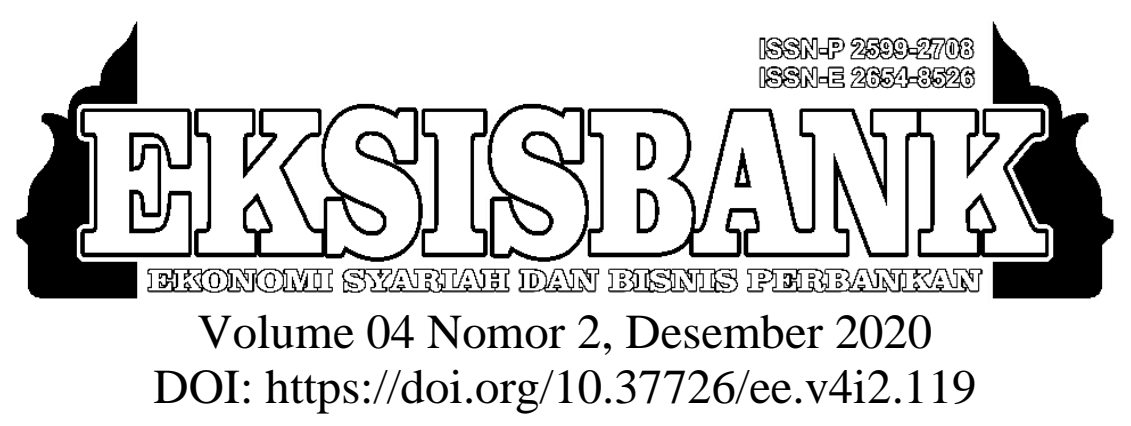

\title{
Pengaruh Pelayanan Islami Terhadap Kepuasan Konsumen Di 212 Mart Purwakarta
}

\author{
Nasih Sariningsih ${ }^{1}$, Saepul Bahri ${ }^{2}$, Ayi Nurbaeti ${ }^{3}$ \\ ${ }^{1,2,3}$ Sekolah Tinggi Ilmu Ekonomi Syariah (STIES) Indonesia Purwakarta \\ ${ }^{1}$ sariningsihnasih@gmail.com \\ ${ }^{2}$ sapulbahri@gmail.com \\ 3ayinurbaeti@gmail.com
}

\begin{abstract}
ABSTRAK
Perkembangan bisnis yang mulai pesat membuat persaingan bisnis begitu ketat. Konsumen dihadapkan dengan beraneka ragam produk sehingga banyak perusahaan-perusahaan menjual produknya dengan berbagai macam bentuk dan inovasi yang dapat membuat konsumen tertarik dengan produk yang dijual, diantaranya perusahaan ritel seperti Indomaret, Alfamart, Yomart, dan berbagai minimarket lainnya. Sehingga terjadilah persaingan untuk dapat memenuhi kebutuhan konsumen dan memberikan kepuasan secara maksimal. 212 Mart merupakan brand minimarket syariah yang menjual berbagai macam kebutuhan sehari-hari. Setiap konsumen berhak atas kenyamanan, keamanan, informasi yang benar dan jujur serta perlakuan atau pelayanan secara benar atas apa yang dibeli. Tujuan dari penelitian ini adalah untuk mengukur dan menganalisis seberapa besar pengaruh pelayanan Islami terhadap kepuasan konsumen di 212 Mart Purwakarta. Adapun populasi jumlah rata-rata konsumen 212 Mart Purwakarta sekitar 120 orang/hari. Rumus penentuan sampel dalam penelitian ini menggunakan rumus Slovin, sehingga menghasilkan sampel sebanyak 92 orang. Pengumpulan data dilakukan dengan cara menyebarkan kuesioner yang menggunakan skala Likert kepada responden sebanyak 92 orang. Metode yang digunakan adalah metode kuantitatif, yaitu metode yang menggunakan angka-angka kemudian dianalisis menggunakan program SPSS versi 25 . Teknik analisa data yang digunakan dalam penelitian ini adalah uji validitas, uji realibilitas, uji asumsi klasik meliputi uji normalitas dan uji linearitas, sedangkan uji hipotesis meliputi uji parsial (t), analisis koefisien determinasi (r2) serta analisis regresi sederhana. Hasil penelitian menunjukkan bahwa variabel independen (Pelayanan Islami) terbukti secara positif dan signifikan berpengaruh terhadap variabel dependen (Kepuasan Konsumen) sebesar 57,7\% dengan nilai signifikansi $0,000<0,05$ dan koefisien regresi $\mathrm{X}$ sebesar 0,281 yang artinya bahwa setiap penambahan $1 \%$ nilai pelayanan Islami, maka nilai kepuasan konsumen bertambah sebesar 0,281 . sedangkan sisanya sebesar $42,3 \%$ oleh variabel lain diluar variabel yang digunakan dalam penelitian ini.
\end{abstract}

Kata kunci- Pelayanan Islami, Kepuasan Konsumen.

EKSISBANK (Ekonomi Syariah dan Bisnis Perbankan), Volume 4, Nomor 2, Desember 2020

http://journal.sties-purwakarta.ac.id/index.php/EKSISBANK/

ISSN: 2654-8526 (Media Online) 2599-2708 (Media Cetak) 


\begin{abstract}
The purpose of this research is to measure and analyze how much influence the Islamic service has on consumer satisfaction at 212 Mart Purwakarta. The sample of this research is 212 Mart Purwakarta consumers as many as 92 people. The formula for determining the sample uses the Slovin formula. Data collection was carried out by distributing questionnaires using a Likert scale to 92 respondents. The method used is a quantitative method, a method that uses numbers and then analyzed using the SPSS version 25 program. Data analysis techniques used in this study are validity, reliability, classical assumption tests include normality and linearity tests, while hypothesis testing include partial test $(t)$, coefficient of determination analysis $(r 2)$ and simple regression analysis. The results showed that the independent variable (Islamic service) was proven to be positive and significant effect on the dependent variable (Consumer Satisfaction) of $57.7 \%$ with a significance value of $0,000<0.05$ and a regression coefficient of $X$ of 0.281 which means that each addition of $1 \%$ value Islamic services, the value of consumer satisfaction increases by 0.281 . while the remaining $42.3 \%$ by other variables outside the variables used in this study.
\end{abstract}

Keywords - Islamic Services, Consumer Satisfaction.

\section{PENDAHULUAN}

Perkembangan bisnis yang mulai pesat membuat persaingan bisnis begitu ketat. Konsumen dihadapkan dengan beraneka ragam produk sehingga banyak perusahaanperusahaan menjual produknya dengan berbagai macam bentuk dan inovasi yang dapat membuat konsumen tertarik dengan produk yang dijual, diantaranya perusahaan ritel seperti Indomaret, Alfamart, Yomart, dan berbagai minimarket lainnya. Sehingga terjadilah persaingan untuk dapat memenuhi kebutuhan konsumen dan memberikan kepuasan secara maksimal.

Grafik 1.1

Penjualan Ritel Indonesia

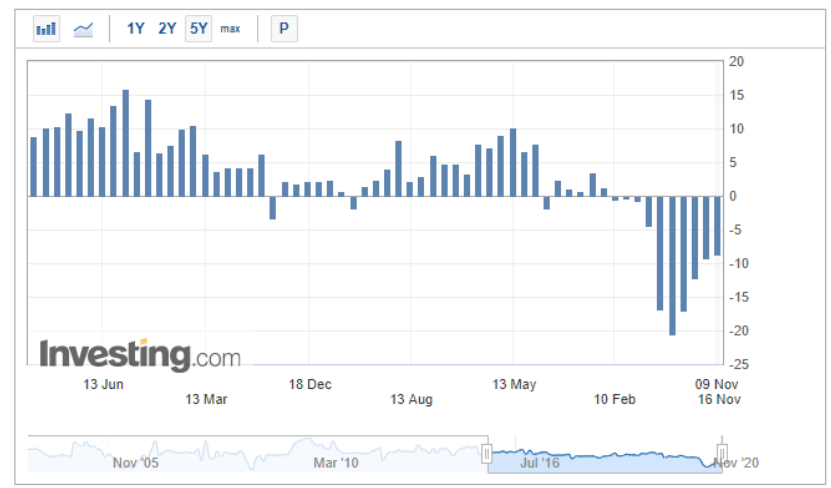

Sumber : $\underline{\text { https://id.investing.com/ }}$
212 Mart merupakan brand minimarket syariah yang menjual berbagai macam kebutuhan sehari-hari. Setiap konsumen berhak atas kenyamanan, keamanan, informasi yang benar dan jujur serta perlakuan atau pelayanan secara benar atas apa yang dibeli (Arifin, 2007). Dalam dunia bisnis termasuk minimarket syariah, kepuasan konsumen menjadi salah satu yang diutamakan karena hal itulah yang akan menentukan berhasil atau tidaknya suatu usaha. Salah satu aspek yang perlu mendapat perhatian dalam dunia bisnis adalah etika. Dalam agama Islam mengajarkan pada umatnya tentang etika dalam berbisnis. Nabi Muhammad SAW dalam berbisnis selalu memperhatikan kepuasan konsumen, menepati janji, tidak menipu, bertanggung jawab, tidak melupakan akhirat dan sebagainya.

Minimarket 212 Mart Purwakarta nampaknya masih sepi dikunjungi konsumen dibandingkan brand minimarket yang sudah lama berdiri dan terkenal. Hal ini dilihat dari banyaknya kendaraan yang parkir didepan minimarket 212 Mart Purwakarta sekitar 70

EKSISBANK (Ekonomi Syariah dan Bisnis Perbankan), Volume 4, Nomor 2, Desember 2020 
kendaraan/hari selama toko beroperasional dari jam 07.00-22.00. Mayoritas konsumen yang berbelanja di 212 Mart Purwakarta yaitu konsumen umum yang berada disekitar toko sedangkan yang merupakan anggota dari koperasi 212 Mart sekitar 20 orang. Adapun para pengurus koperasi 212 Mart berbelanja setiap bulan, sisanya konsumen yang hanya transit. Ini menunjukkan bahwa omzet penjualan masih minim didapatkan. Sebenarnya omzet penjualan di 212 Mart Purwakarta mengalami peningkatan yang signifikan tiap bulannya namun belum mencapai target yang telah ditentukan ( $\mathrm{N}$. Hartati, 2019). Lain halnya dengan Alfamidi, konsumen yang berbelanja disana lebih banyak bahkan bisa mencapai $2 \mathrm{x}$ lipat konsumen yang berbelanja di 212 Mart Purwakarta.

Dalam dunia bisnis bidang ritel kepuasan konsumen menjadi prioritas utama dalam rangka menarik minat konsumen. Namun pada kenyataannya Alfamart, Alfamidi, Indomaret lebih ramai dikunjungi konsumen dibandingkan 212 Mart Purwakarta yang menggunakan pelayanan Islami. Bisnis ritel berupa minimarket sudah seharusnya mampu menciptakan keunggulan masing-masing baik dari segi produk maupun dari segi jasa yang ditawarkan sehingga konsumen mendapatkan kepuasan karena kebutuhan terpenuhi secara baik. Salah satu konsumen 212 Mart Purwakarta menuturkan kepuasan berbelanja atas pelayanan Islami yang diterapkan di 212 Mart Purwakarta meliputi pegawai yang ramah, berpakaian yang syar'i, tidak adanya kecurangan dalam berbelanja, barang yang dibeli dapat ditukar kembali asalkan ada akad, dan lain sebagainya. Namun dari segi produk menyatakan bahwa produk yang tersedia dan ditawarkan oleh 212 Mart tidak sebanyak produk yang dijual di bisnis ritel konvensional yang sudah ada seperti Indomaret dan Alfamart.
Minimarket 212 Mart sebagai perusahaan dibidang ritel dengan konsep Islami tentunya harus memiliki strategi pemasaran yang baik agar lebih dikenal pada kalangan masyarakat umum, yang mana hingga saat ini keberadaan 212 Mart hanya terkenal dikalangan akademisi Islam namun asing bagi masyarakat secara umum.

Dilihat dari pemaparan diatas penulis tertarik meneliti dan mengkaji lebih dalam tentang pelayanan Islami terhadap kepuasan konsumen. Maka dari itu, penulis mengambil judul penelitian "Pengaruh Pelayanan Islami Terhadap Kepuasan Konsumen Di 212 Mart Purwakarta".

Penulis menggunakan beberapa teori dalam penelitian ini, yaitu teori tentang pelayanan Islami dan kepuasan konsumen.

\section{A. Pelayanan Islami}

\section{Pelayanan}

Menurut AS. Moenir, pelayanan adalah proses pemenuhan kebutuhan melalui aktivitas orang lain secara langsung (Moenir, 1996). Menurut Kasmir, pelayanan adalah tindakan atau perbuatan seseorang atau organisasi untuk memberikan kepuasan kepada pelanggan atau nasabah (Kasmir, 2005). Sedangkan menurut Kotler, pelayanan adalah setiap tindakan atau kegiatan yang dapat ditawarkan oleh suatu pihak kepada pihak lain, yang pada dasarnya tidak berwujud dan tidak mengakibatkan kepemilikan apapun (Kotler \& Keller, 2009).

Indikator pelayanan menurut Philip Kotler adalah sebagai berikut:
a. Reliability
b. Responsiveness
c. Assurance
d. Emphaty
e. Tangible

\section{Islami}

Kata Islami berasal dari bahasa Arab alIslam, disebut juga ad-din yang artinya jalan hidup yang ada disisi Allah SWT, tunduk, 
patuh, berserah diri kepada perintah dan larangan yang memberi perintah tanpa penolakan (Azis, 2013). Kata Islami memberikan arti sebagai perbuatan refleksi atas perwujudan dari nilai-nilai ajaran Islam itu sendiri. Kata Islam sebagai ajaran diidentikkan dengan kata syariat yang sepadan dengan makna perundang-undangan yang diturunkan Allah SWT melalui Nabi Muhammad SAW untuk seluruh umat manusia baik menyangkut masalah ibadah, akhlak, makanan, minuman, pakaian, maupun muamalah (interaksi sesama manusia dalam berbagai aspek kehidupan guna meraih kebahagiaan di dunia dan akhirat (Azis, 2013).

Setelah mengetahui makna atau pengertian satu persatu dari kata pelayanan dan Islami maka dapat digabungkan makna keduanya adalah bahwa pelayanan Islami merupakan pelayanan yang dilakukan berdasarkan prinsip Islam atau syariat Islam berdasarkan Al-Qur'an dan hadits dengan mencontoh prinsip dagang Nabi Muhammad SAW.

Indikator pelayanan secara Islami yaitu mencontoh empat sifat Nabi Muhammad SAW, diantaranya (Sula \& Kartajaya, 2006):
a. Shiddiq (Jujur)
b. Amanah (Bertanggung Jawab)
c. Tabligh (Komunikatif)
d. Fathonah (Cerdas)

\section{B. Kepuasan Konsumen}

Menurut Fandy Tjiptono \& Gregorius Chandra, kata kepuasan (satisfaction) berasal dari bahasa latin "satis" artinya cukup baik, memadai dan "facto" berarti melakukan atau membuat. Kepuasan bisa diartikan sebagai "upaya pemenuhan sesuatu" atau "membuat sesuatu memadai" (Tjiptono \& Chandra, 2004).

Menurut Kotler, kepuasan adalah perasaan kecewa atau senang seseorang yang muncul setelah membandingkan kinerja (hasil) produk yang dipikirkan terhadap kinerja (hasil) yang diharapkan (Kotler \& Keller, 2009).
Konsumen adalah pelaku ekonomi yang melakukan kegiatan konsumsi, yang mana mereka membeli atau menggunakan suatu produk baik barang ataupun jasa. Menurut pengertian Pasal 1 angka 2 UU Perlindungan Konsumen, konsumen adalah setiap orang pemakai barang dan/atau jasa yang tersedia dalam masyarakat, baik bagi kepentingan diri sendiri, keluarga, orang lain, maupun makhluk hidup lain dan tidak untuk diperdagangkan (Susanto, 2008). Jadi, kepuasan konsumen dalam penelitian ini yaitu tingkat perasaan dimana konsumen merasa puas atas pelayanan Islami yang diberikan oleh 212 Mart Purwakarta.

Indikator kepuasan konsumen menurut Kotler, diantaranya:

a. Loyal terhadap produk.

b. Adanya komunikasi dari mulut ke mulut secara positif.

c. Pedagang menjadi pertimbangan utama ketika membeli produk.

Maksud penulis melakukan penelitian ini, yaitu:

a. Untuk menjelaskan pengaruh pelayanan Islami terhadap kepuasan konsumen di 212 Mart Purwakarta.

b. Untuk menjelaskan besarnya pengaruh pelayanan Islami terhadap kepuasan konsumen di 212 Mart Purwakarta.

\section{TINJAUAN PUSTAKA}

Penelitian tentang Pengaruh Pengetahuan Calon Nasabah Terhadap Keputusan Menjadi Nasabah Bank Syariah sudah banyak dilakukan oleh peneliti sebelumnya, tapi tentu saja mempunyai perbedaan-perbedaan antara penelitian ini dengan penelitian sebelumnya. Berikut adalah penelitian sebelumnya yang meneliti tentang Pengaruh Pengetahuan Calon Nasabah Terhadap Keputusan Menjadi Nasabah Bank Syariah;
1.Pengaruh Kualitas
Terhadap Kepuasan
Pelayanan Retail
Konsumen Pada 
Swalayan Mart 212 Di Kota Medan (Hadian \& Rahmat, 2019)

Tujuan penelitian yang ingin dicapai dalam penelitian ini adalah untuk mengetahui besarnya pengaruh kualitas pelayanan swalayan 212 Mart yaitu aspekfisik, kehandalan, interaksi pribadi, pemecahan masalah dan kebijakan terhadap kepuasan konsumen swalayan 212 Mart di Kota Medan. Jenis penelitian ini menggunakan penelitian kuantitatif yang berjenis asosiatif. Penelitian ini akan dilakukan dilakukan pada pelanggan swalayan 212 Mart yang berbelanja pada swalayan 212 Mart di wilayah Kota Medan. Populasi dalam penelitian ini adalah masyarakat yang melakukan pembelian pada swalayan 212 Mart. Sampel dalam penelitian ini adalah sebesar 100 orang. Untuk teknik pengambilan sampel menggunakan teknik nonprobability sampling yaitu dengan metode purposive sampling. Pada penelitian ini dimensi kebijakan kualitas pelayanan berpengaruh positif dan signifikan terhadap kepuasan konsumen pada swalayan swalayan 212 Mart.

\section{Pengaruh Store Atmosphere Terhadap}

Keputusan Pembelian Konsumen Muslim

Di 212 Mart Banda Aceh (Matondang \&

Kesuma, 2020)

Penelitian ini bertujuan untuk mengukur pengaruh store atmosphere terhadap keputusan pembelian konsumen muslim di 212 Mart Banda Aceh. Sampel yang digunakan dalam penelitian ini adalah masyarakat Kota Banda Aceh yang melakukan pembelian atau mengunjungi 212 Banda Aceh Mart yang berjumlah 170 responden. Alat pengumpulan data yang digunakan dalam penelitian ini adalah kuesioner. Teknik pengambilan sampel yang digunakan adalah accidental sampling. Regresi Linier Berganda digunakan sebagai metode analisis untuk mengetahui pengaruh dari semua variabel yang terlibat. Hasil penelitian menunjukkan bahwa secara parsial variabel kebersihan berpengaruh terhadap keputusan pembelian, musik tidak berpengaruh terhadap keputusan pembelian, aroma berpengaruh terhadap keputusan pembelian, suhu tidak berpengaruh terhadap keputusan pembelian, pencahayaan berpengaruh terhadap keputusan pembelian, warna tidak berpengaruh terhadap keputusan pembelian, tampilan / tata letak berpengaruh terhadap keputusan pembelian. keputusan, dan secara bersamaan kebersihan, musik, aroma, suhu, pencahayaan, warna, dan tampilan / tata letak mempengaruhi keputusan pembelian.

\section{Pengaruh Kepuasan Dan Kualitas}

Pelayanan Karyawan 212 Mart Terhadap Loyalitas Konsumen (Studi Kasus Pada Konsumen 212 Mart Mutiara, Cibarusah Bekasi) (R. Hartati, 2019)

Pengembangan koperasi 212 Mart ini masih banyak yang belum berjalan dengan baik. Dengan demikian, peneliti tertarik melakukan penelitian ini karena masih banyaknya masalah dalam pengembangan koperasi ini yang belum ter realisasi oleh anggota koperasi 212 Mart. Pengelola 212 Mart masih belum menjalankan program kerja dan selain itu masih banyak fasilitas - fasilitas di koperasi ini yang masih minim seperti kurang nya AC (Air Conditioner), Toilet yang belum di renovasi, Produk yang tidak ada, area parker yang sempit, kulkas untuk minuman hanya beberapa. Ditambah masyarakat yang belum paham dan mengetahui koperasi 212 Mart.

Adapun tujuan penelitian ini adalah untuk Mengetahui pengaruh kepuasan terhadap loyalitas konsumen pada 212 Mart di Mutiara Cibarusah, Mengetahui pengaruh kualitas pelayanan karyawan 212 Mart terhadap loyalitas konsumen di Mutiara Cibarusah, Mengetahui pengaruh kepuasan dan kualitas 
pelayanan 212 Mart secara bersama sama terhadap loyalitas konsumen di Mutiara Cibarusah. Metode pengumpulan data penelitian ini yaitu dengan wawancara, observasi dan dokumentasi. Sumber data yang digunakan yaitu sumber data primer dan sekunder. Analisis data menggunakan pendekatan Kuantitatif Deskriptif dengan mengkaji sistem pengembangan koperasi.

Berdasarkan hasil penelitian yang telah dilakukan, maka ditarik kesimpulan pada pengujian pengaruh kepuasan dan kualitas pelayanan terhadap loyalitas konsumen 212 Mart di Mutiara Cibarusah sebagai berikut:Berdasarkan hasil analisis regresi pada Uji T (Parsial) pada varibel kepuasan diperoleh nilai Thitung lebih besar daripada $\mathrm{T}$ tabel, maka dapat disimpulkan bahwa H01 ditolak dan Ha1 diterima yang artinya, bahwa kepuasan secara parsial berpengaruh terhadap loyalitas konsumen 212 Mart di Mutiara Cibarusah.Berdasarkan hasil analisis regresi pada Uji T (Parsial) pada variabel kualitas pelayanan diperoleh $\mathrm{T}$ hitung lebih besar daripada $\mathrm{T}$ tabel, maka dapat disimpulkan bahwa $\mathrm{H} 02$ ditolak dan $\mathrm{Ha} 2$ diterima yang artinya, bahwa kualitas pelayanan secara parsial berpengaruh terhadap loyalitas konsumen 212 Mart di Mutiara Cibarusah.Berdasarkan hasil analisis regresi pada Uji F (Simultan) diperoleh nilai Fhitung lebih besar daripada $\mathrm{F}$ tabel, maka dapat disimpulkan bahwa H03 ditolak dan Ha3 diterima, yang artinya kepuasan dan kualitas pelayanan berpengaruh secara simultan terhadap loyalitas konsumen 212 Mart di Mutiara Cibarusah.

4.Pengaruh Motivasi, Lingkungan Kerja Dan Kinerja Terhadap Kepuasan Kerja Karyawan (Studi Kasus Pada 212 Mart Medan) (Wati \& Murtani, 2020)

212 Mart merupakan sebuah minimarket pertama yang mengambil konsep syariah yang masih dalam proses pengembangan, sehingga para karyawan pada 212 Mart masih membutuhkan motivasi yang tinggi dari seorang pemimpin untuk dapat mencapai tujuan perusahaan. Adapun maksud dari penelitian ini adalah untuk mengetahui apakah motivasi, lingkungan kerja dan kinerja karyawan 212 mart berpengaruh terhadap kepuasan kerja karyawan 212 Mart Medan? Penelitian ini menggunakan penelitian jenis kuantitatif dengan banyak populasi dan sampel sebesar 30 responden dengan metode Non Propability Sampling dengan tekhnik Sampling Jenuh. Pengumpulan data dengan menggunakan kuesioner dan wawancara dengan menggunakan pengukuran skala likert. Analisis data yang digunakna berupa analisis regresi linier berganda dengan taraf signifikan $5 \%$. Pada variabel motivasi didapat nilai $r$ statistic sebesar thitung sebesar $2.297>$ ttabel 2.056 dengan nilai signifikan $0,030<0,05$ maka dianggap signifikan dan berpengeruh positif, dan nilai yang didapat untuk variabel lingkungan kerja nilai statistic sebesar thitung $9.154>$ ttabel 2.056 dengan nilai signifikan $0,000<0,05$ yang berarti signifikan dan memiliki pengaruh positif, dan untuk variabel kinerja didapat nilai $r$ statistic sebesar thitung $1.728<$ ttabel 2.056 dengan nilai signifikan $0,095>0,05$ berarti pada variabel kinerja tidak memiliki pengaruh positif dan tidak signifikan. Berdasarkan hasil uji Koefisen Determinasi (R2) dengan melihat nilai Adjusted R Square sebesar 0,810 berarti bahwa kepuasan kerja karyawan dapat dipengaruhi oleh variabel motivasi, lingkungan kerja dan kinerja sebesar $81 \%$.

\section{Brand Image 212 Mart Dalam} Meningkatkan Penjualan Produk Perspektif Manajemen Dakwah (Ramdhani et al., 2020)

Persoalan yang dibahas dalam skripsi ini adalah bagaiamana strategi brand image 212 
mart Jalan Mahakam Lingkar Barat Kota Bengkulu dalam meningkatkan penjualan produk perspektif manajemen dakwah. Penelitian ini bertujuan untuk mengetahui dan mendeskripsikan strategi brand image 212 mart Jalan Mahakam Lingkar Barat Kota Bengkulu dalam meningkatkan penjualan produk perspektif manajemen dakwah. Metode penelitian yang digunakan adalah metode deskriptif, jenis penelitian ini kualitatif adalah penelitian lapangan dengan pengumpulan data melalui wawancara, observasi dan dokumentasi. Hasil penelitian menunjukan bahwa strategi brand image 212 mart Jalan Mahakam Lingkar Barat Kota Bengkulu dalam meningkatkan penjualan produk perspektif manajemen dakwah sudah berjalan dengan baik, yaitu menggunakan beberapa strategi meliputi promosi, menjadi agen utama, penampilan dan pelayanan, serta brand image 212 mart tidak terlepas dari unsur-unsur manajemen dakwah, yaitu terkait dengan Da'i, Mad'u, Maddah, Wasilah, Thariqoh dan Atsar.

\section{Faktor Yang Mempengaruhi Konsumen} Untuk Memilih 212 Mart Surabaya Sebagai Tempat Untuk Berbelanja (Gunawarman \& Ratnasari, 2020)

Penelitian ini bertujuan untuk mengetahui faktor-faktor yang mempengaruhi keputusan konsumen dalam berbelanja di minimarket syariah 212 di Wonorejo, Surabaya, di tengah pesatnya pertumbuhan waralaba 212 Mart di seluruh Indonesia. Metode yang digunakan dalam penelitian ini adalah analisis faktor eksploratif. Karakteristik populasi yang digunakan dalam penelitian ini adalah konsumen 212 Mart Surabaya dan orangorang yang tinggal di sekitar Wonorejo yang pernah bertransaksi di 212 Mart. Jumlah sampel yang digunakan dalam penelitian ini adalah 30 responden untuk tes pendahuluan dan 95 responden untuk tes utama. Penelitian ini menggunakan convenience sampling untuk menarik sampel. Penelitian ini menemukan bahwa terdapat lima faktor yang mempengaruhi keputusan konsumen dalam berbelanja di 212 Mart Surabaya. Kelima faktor tersebut adalah kecocokan konsumen terhadap barang halal, rekomendasi dari teman-teman yang memiliki visi yang sama tentang gerakan 212, persediaan barang, area parkir dan suasana yang Islami.

7.Analisis Pengaruh Gaya Kepemimpinan Terhadap Kepuasan Kerja,Kinerja Dan Loyalitas Karyawan 212 Mart Kota Medan (Rahwani \& Murtani, 2020)

Penelitian ini bertujuan untuk mengetahui Pengaruh Gaya Kepemimpinan Terhadap Kepuasan Kerja,Kinerja Dan Loyalitas Karyawan 212 Mart Kota Medan. Penelitian ini merupakan jenis penelitian Kuantitatif. Keberhasilan organisasi dalam mencapai tujuan yang ingin diraih bergantung pada kepemimpinannya yaitu apakah kepemimpinan tersebut mampu menggerakkan semua sumber daya yang ada secara efektif dan efisien serta terpadu dalam mencapai tujuan organisasi dan meningkatkan kinerja. Adapun yang menjadi masalah penelitian ini adalah "Analisis Pengaruh Gaya Kepemimpinan Terhadap Kepuasan Kerja,Kinerja dan Loyalitas Karyawan 212 Mart Medan". Penelitian ini mencoba untuk mengetahui seberapa besar pengaruh gaya kepemimpinan terhadap kepuasan kerja 212 Mart Kota Medan khususnya. Tujuan penelitian ini untuk menganalisis pengaruh variabel gaya kepemimpinan (X1) terhadap kepuasan kerja (Y1), kinerja (Y2), dan loyalitas karyawan (Y3). Serta variabel mana yang paling berpengaruh terhadap variabel (X).Dalam penelitian ini data dikumpulkan melalui metode kuesioner dengan penyebaran angket jenis skala likert terhadpa 30 responden yang merupakan karyawan 212 Mart Kota Medan. 
Kemudian dilakukan analisis terhadap datadata yang didapat dengan menggunakan metode kuantitatif. analisis kuantitatif yang digunakan meliputi uji normalitas, validitas, reliabilitas, uji asumsi klasik, uji hipotesis, uji $\mathrm{t}$, uji f, uji (R2). Teknik analisis data yang digunakan adalah analisis linier berganda yang berfungsi membuktikan hipotesis penelitian.Hasil analisis yaitau bahwa ketiga variabel dependen berpengaruh positif terhadap variabel independen, dan yang paling dominan dalam mempengaruhi variabel independen adalah variabel $\mathrm{Y} 1$ (kepuasan kerja) melalui uji t, uji f dan uji R.

\section{Pengaruh Bauran Pemasaran Terhadap}

Keputusan Pembelian Pada 212 Mart Banjarmasin (Hilmi, 2020)

Tujuan penelitian ini adalah untuk mengetahui pengaruh variabel independen yang terdiri dari Produk, Harga, Tempat dan Promosi baik secara simultan maupun parsial terhadap variabel dependen keputusan pembelian pada 212 Mart Banjarmasin. Serta ingin mengetahui variabel dominan yang mempengaruhi keputusan pembelian pada 212 Mart Banjarmasin. Data yang digunakan adalah hasil penyebaran kuesioner kepada responden yang berbelanja di 212 Mart Banjarmasin. Teknik pemilihan sampel adalah Accindental Sampling dengan jumlah konsumen 70 orang. Teknik pengolahan data menggunakan SPSS (Paket Statistik untuk Ilmu Sosial). Hasil penelitian menunjukkan bahwa secara simultan variabel Produk, Harga, Tempat dan Promosi berpengaruh signifikan terhadap variabel keputusan pembelian di 212 Mart Banjarmasin sebesar 14.671. Secara parsial hanya variabel tempat yang berpengaruh terhadap keputusan pembelian pada 212 Mart Banjarmasin sebesar 3,255 dengan nilai signifikansi 0,002 . Sedangkan variabel Produk $(0,856)$, Harga $(1,627)$ dan Promosi $(1,624)$ tidak berpengaruh signifikan terhadap keputusan pembelian pada 212 Mart Banjarmasin. Variabel yang berpengaruh dominan adalah Place with Beta Value on Standardized Coefficients (0,382), artinya menurut persepsi konsumen faktor tempat menjadi sesuatu yang dianggap penting dalam upaya membuat keputusan pembelian di 212 Mart. Mengacu pada koefisien terminasi ( $R$ Square) sebesar 0.456 maka keputusan pembelian pada 212 Mart $45.6 \%$ dipengaruhi oleh variabel produk, harga, tempat dan promosi. Sedangkan sisanya sebesar $45,4 \%$ keputusan pembelian konsumen dipengaruhi oleh variabel lain yang tidak dimasukkan dalam penelitian ini.

9. Pengaruh Produk Dan Harga Terhadap Keputusan Pembelian Pada Konsumen 212 Mart Condet Batu Ampar (Destarini \& Prambudi, 2020)

Minimarket 212 Mart Condet menjadi objek yang menarik bagi para peneliti karena minimarket baru ini muncul dengan latar belakang aksi bela umat Islam atas penodaan agama (Q.S. Al-Maidah: 51). Penelitian ini bertujuan untuk menganalisis Pengaruh Produk dan Harga terhadap Keputusan Pembelian pada konsumen Minimarket 212 Mart Condet. Data yang digunakan dalam penelitian ini adalah data primer yang diperoleh dari angket. Metode pengolahan data yang digunakan peneliti adalah analisis regresi linier berganda. Penelitian ini menggunakan program komputer SPSS versi 22.0. Hasil penelitian menunjukkan bahwa produk memiliki pengaruh yang positif dan signifikan yang artinya semakin positif atau baik atau baik produk tersebut maka semakin kuat pula keputusan pembeliannya. Hasil penelitian Price berpengaruh negatif dan tidak signifikan terhadap keputusan pembelian, artinya jika negatif berarti berbeda arah semakin tinggi harga atau semakin tinggi keputusan pembelian menurun. 
10. Analisis Keterkaitan Kualitas Pelayanan Terhadap Consumer Satisfaction Minimarket 212 Di Kota Medan (Dayu, 2019)

Penelitian ini bertujuan untuk menguji kualitas pelayanan yang mempengaruhi kepuasan konsumen yang datang berkunjung atau berbelanja kebutuhan sehari-hari di Minimarket 212 (212 Mart) kota Medan dan sekitarnya. Populasi dalam penelitian ini adalah seluruh konsumen yang datang dan berbelanja di Minimarket 212 (212 Mart) di kota Medan dan sekitarnya. Teknik pengambilan sampel menggunakan insidental sampling yang dikombinasikan dengan rumus moe (marginal of maximal error), sehingga jumlah sampel penelitian sebanyak 100 orang. Teknik analisis yang digunakan dalam penelitian ini adalah analisis regresi linier berganda dengan aplikasi SPSS versi 21.0 for Windows yang bertujuan untuk memperoleh gambaran yang komprehensif tentang hubungan variabel penelitian. Hasil penelitian ini menunjukkan variabel kualitas pelayan berupa reliabilitas, jaminan dan empati memiliki pengaruh yang signifikan terhadap kepuasan pelanggan yang datang dan berbelanja di Minimarket 212 (212 Mart) di kota Medan dan sekitarnya. Sedangkan variabel kualitas pelayanan berupa tengible dan responsiveness tidak berpengaruh signifikan terhadap kepuasan konsumen yang datang dan berbelanja di Minimarket 212 (212 Mart) di kota Medan dan sekitarnya.

\section{METODOLOGI PENELITIAN}

Berdasarkan variabel yang diteliti, masalah yang dirumuskan dan hipotesis yang diajukan maka peneliti melakukan penelitian dengan menggunakan metode kuantitatif. Peneliti mengolah data berupa angka-angka yang dihasilkan dari penyebaran kuesioner kepada responden dengan menggunakan aplikasi
SPSS versi 25. Selain itu, peneliti melakukan wawancara kepada pegawai dan konsumen 212 Mart Purwakarta guna memperoleh data yang diperlukan.

Teknik analisa data yang digunakan oleh peneliti yaitu statistik deskriptif. Populasi yang diteliti yaitu seluruh konsumen 212 Mart Purwakarta dengan pengambilan sampel berjumlah 92 orang menggunakan rumus Slovin.

Penulis menggunakan beberapa teknik analisa data untuk menguji hasil statistic yang telah dilakukan, diantaranya:

\section{A. Uji Validitas}

Uji validitas digunakan untuk mengukur ketepatan alat ukur yang digunakan dalam mengkorelasikan skor jawaban setiap pertanyaan. Kita bandingkan hasil $\mathrm{r}_{\text {hitung }}$ dengan $r_{\text {tabel. }}$ Jika $r_{\text {hitung }}>r_{\text {tabel }}$, maka data valid namun jika $r_{\text {hitung }}<r_{\text {tabel }}$, maka data tidak valid. Besarnya degree of freedom $(\mathrm{df})=\mathrm{n}-2$, dalam hal ini $n$ adalah jumlah sampel.

Pengolahan data penelitian ini menggunakan software SPSS versi 25 untuk menguji tingkat validitas instrumen. Dalam pengujian validitas dilakukan uji signifikan dengan membandingkan $r$ hitung dan $r$ tabel. Besarnya degree of freedom $(\mathrm{df})=\mathrm{n}-2$, dalam hal ini $\mathrm{n}$ adalah jumlah sampel. Pada kasus ini besarnya df dapat dihitung 92-2=90 atau df 90 dengan signifikansi 5\% didapat $r$ tabel 0,207.

Tabel 3.1

Uji Validitas Pelayanan Islami (X)

\begin{tabular}{|l|c|c|c|c|}
\hline $\begin{array}{c}\text { Pernyata } \\
\text { an }\end{array}$ & $\mathbf{r}$ hitung & $\begin{array}{c}\text { Signifika } \\
\text { nsi }\end{array}$ & r tabel & $\begin{array}{c}\text { Kesimpul } \\
\text { an }\end{array}$ \\
\hline P1 & 0,721 & 0,05 & 0,207 & Valid \\
\hline P2 & 0,706 & 0,05 & 0,207 & Valid \\
\hline P3 & 0,632 & 0,05 & 0,207 & Valid \\
\hline P4 & 0,767 & 0,05 & 0,207 & Valid \\
\hline P5 & 0,504 & 0,05 & 0,207 & Valid \\
\hline P6 & 0,708 & 0,05 & 0,207 & Valid \\
\hline P7 & 0,848 & 0,05 & 0,207 & Valid \\
\hline P8 & 0,791 & 0,05 & 0,207 & Valid \\
\hline P9 & 0.549 & 0,05 & 0,207 & Valid \\
\hline P10 & 0,614 & 0,05 & 0,207 & Valid \\
\hline P11 & 0,763 & 0,05 & 0,207 & Valid \\
\hline P12 & 0,699 & 0,05 & 0,207 & Valid \\
\hline P13 & 0,730 & 0,05 & 0,207 & Valid \\
\hline P14 & 0,364 & 0,05 & 0,207 & Valid \\
\hline
\end{tabular}

EKSISBANK (Ekonomi Syariah dan Bisnis Perbankan), Volume 4, Nomor 2, Desember 2020 http://journal.sties-purwakarta.ac.id/index.php/EKSISBANK/ 


\begin{tabular}{|l|c|c|c|c|}
\hline $\begin{array}{c}\text { Pernyata } \\
\text { an }\end{array}$ & r hitung & $\begin{array}{c}\text { Signifika } \\
\text { nsi }\end{array}$ & r tabel & $\begin{array}{c}\text { Kesimpul } \\
\text { an }\end{array}$ \\
\hline P15 & 0,678 & 0,05 & 0,207 & Valid \\
\hline P16 & 0,634 & 0,05 & 0,207 & Valid \\
\hline P17 & 0,594 & 0,05 & 0,207 & Valid \\
\hline P18 & 0,690 & 0,05 & 0,207 & Valid \\
\hline
\end{tabular}

Sumber: diolah oleh SPSS versi 25, 2019.

Berdasarkan tabel 3.1 uji validitas menggunakan pearson product moment pada 18 item pernyataan yang diujikan, diperoleh hasil bahwa masing-masing item pernyataan memiliki nilai $\mathrm{r}>0,207$ dan signifikansi < 0,05 maka ditarik kesimpulan bahwa pernyataan valid.

Tabel 3.2

Uji Validitas Kepuasan Konsumen (Y)

\begin{tabular}{|l|c|c|c|c|}
\hline Pernyataan & $\begin{array}{c}\text { r } \\
\text { hitung }\end{array}$ & Signifikansi & $\begin{array}{c}\text { r } \\
\text { tabel }\end{array}$ & Kesimpulan \\
\hline P19 & 0,757 & 0,05 & 0,207 & Valid \\
\hline P20 & 0,719 & 0,05 & 0,207 & Valid \\
\hline P21 & 0,714 & 0,05 & 0,207 & Valid \\
\hline P22 & 0,694 & 0,05 & 0,207 & Valid \\
\hline P23 & 0,747 & 0,05 & 0,207 & Valid \\
\hline P24 & 0,657 & 0,05 & 0,207 & Valid \\
\hline
\end{tabular}

Sumber: diolah oleh SPSS versi 25, 2019.

Berdasarkan tabel 3.2 uji validitas menggunakan pearson product moment pada 6 item pernyataan yang diujikan, dari tabel diatas diperoleh hasil bahwa masing-masing item pernyataan memiliki nilai $r>0,207$ dan signifikansi $<0,05$, maka ditarik kesimpulan bahwa pernyataan valid.

\section{B. Uji Reliabilitas}

Reliabilitas adalah alat untuk mengukur suatu kestabilan dan konsistensi responden dalam menjawab hal yang berkaitan dengan kontruk-kontruk pertanyaan yang merupakan dimensi suatu variabel dan disusun dalam bentuk kuesioner (Sujarweni, 2015). Butir pertanyaan yang sudah dinyatakan valid dalam uji validitas selanjutnya ditentukan reliabilitasnya dengan kriteria jika $r$ alpha $>r$ tabel maka pertanyaan reliable namun jika $\mathrm{r}_{\text {alpha }}$ $<\mathrm{r}_{\text {tabel }}$ maka pertanyaan tidak reliable.

Uji reliabilitas dapat dilakukan secara bersama-sama terhadap seluruh item pertanyaan. Butir pertanyaan yang sudah dinyatakan valid dalam uji validitas selanjutnya ditentukan reliabilitasnya. Instrumen penelitian dikatakan reliabel jika nilai $\mathrm{r}$ hitung $>\mathrm{r}$ table atau apabila nilai signifikansi $<0,05$.

\section{a. Uji Reliabilitas Variabel Pelayanan Islami (X)}

Hasil uji reliabilitas diperoleh $\mathrm{r}$ hitung $(0,922)>r$ table $(0,60)$. Hal ini menunjukkan bahwa instrumen variabel pelayanan Islami dikatakan reliabel.

Tabel 3.3

Uji Reliabilitas Pelayanan Islami (X)

\begin{tabular}{|c|c|}
\hline \multicolumn{2}{|c|}{ Reliability Statistics } \\
\hline Cronbach's Alpha & N of Items \\
\hline 0,922 & 18 \\
\hline
\end{tabular}

Sumber: diolah oleh SPSS versi 25, 2019.

\section{b. Uji Reliabilitas Variabel Kepuasan Konsumen(Y)}

Hasil uji reliabilitas diperoleh $r$ hitung $(0,797)>r$ table $(0,60)$. Hal ini menunjukkan bahwa instrumen variabel pelayanan Islami dikatakan reliabel.

Tabel 3.4

Uji Reliabilitas Kepuasan Konsumen (Y)

\begin{tabular}{|l|c|}
\hline \multicolumn{2}{|c|}{ Reliability Statistics } \\
\hline Cronbach's Alpha & N of Items \\
\hline 0,797 & 6 \\
\hline
\end{tabular}

Sumber: diolah oleh SPSS versi 25, 2019.

\section{Uji Asumsi Klasik}

\section{Uji Normalitas}

Uji normalitas bertujuan untuk mengetahui nilai residual berdistribusi normal atau tidak. Model regresi yang baik adalah memiliki nilai residual yang berdistribusi normal. Jika nilai signifikansi >0,05, maka nilai residual berdistribusi normal namun jika nilai signifikansi $<0,05$, maka nilai residual tidak berdistribusi normal. Uji normalitas dapat dideteksi melalui dua pendekatan grafik, yaitu analisa grafik histogram dan analisa grafik normal p-plot yang membandingkan antara 
dua observasi dengan distribusi yang mendekati distribusi normal.

Tabel 3.5

Uji Normalitas

\begin{tabular}{|c|c|c|}
\hline \multicolumn{3}{|c|}{ One-Sample Kolmogorov-Smirnov Test } \\
\hline & & $\begin{array}{l}\text { Unstandardized } \\
\text { Residual }\end{array}$ \\
\hline \multicolumn{2}{|l|}{$\mathrm{N}$} & \\
\hline \multirow{2}{*}{$\begin{array}{l}\text { Normal } \\
\text { Parameters }\end{array}$} & Mean & 0,0000000 \\
\hline & $\begin{array}{l}\text { Std. } \\
\text { Deviation }\end{array}$ & 1,54670790 \\
\hline \multirow{3}{*}{$\begin{array}{l}\text { Most Extreme } \\
\text { Differences }\end{array}$} & Absolute & 0,085 \\
\hline & Posi & 0,062 \\
\hline & Negative & $-0,085$ \\
\hline \multicolumn{2}{|l|}{ Test Statistic } & 0,085 \\
\hline Asymp. Sig. (2 & iled) &, $099^{c}$ \\
\hline \multicolumn{3}{|c|}{ a. Test distribution is Normal. } \\
\hline \multicolumn{3}{|c|}{ b. Calculated from data. } \\
\hline
\end{tabular}

Sumber: diolah oleh SPSS versi 25, 2019.

Berdasarkan hasil tabel 3.5 diperoleh hasil nilai signifikansi 0,099>0,05 maka dapat ditarik kesimpulan bahwa data memiliki nilai residual berdistribusi normal. Uji normalitas dapat dideteksi pula dengan dua pendekatan yaitu menggunakan analisa grafik histogram dan grafik normal p-plot.

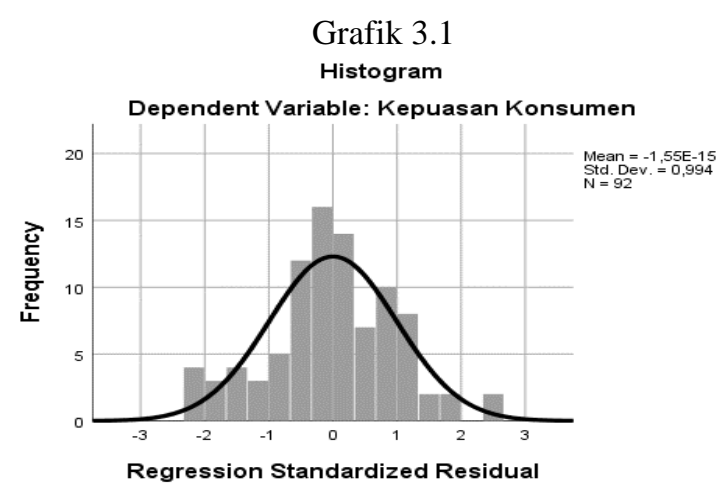

Grafik 3.2

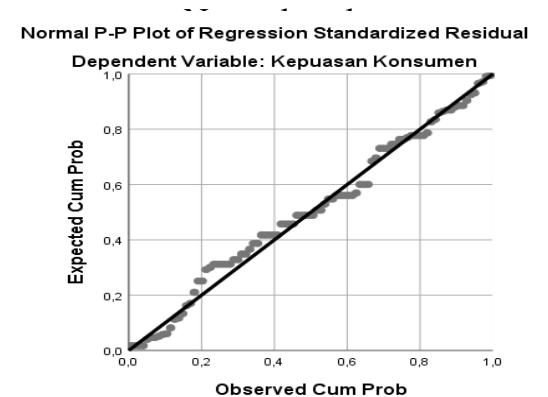

2. Uji Linearitas

Uji linearitas berfungsi untuk mengetahui bentuk hubungan antara variabel bebas dengan variabel terikat. Adapun kriteria pengujian yang digunakan yaitu jika nilai signifikansi deviation from linearity $>0,05$, maka terdapat hubungan yang linear antara variabel bebas dengan variabel terikat, sedangkan jika nilai signifikansi deviation from linearity $<0,05$, maka tidak terdapat hubungan yang linear antara variabel bebas dengan variabel terikat.

\section{Tabel 3.6}

Hasil Uji Linearitas

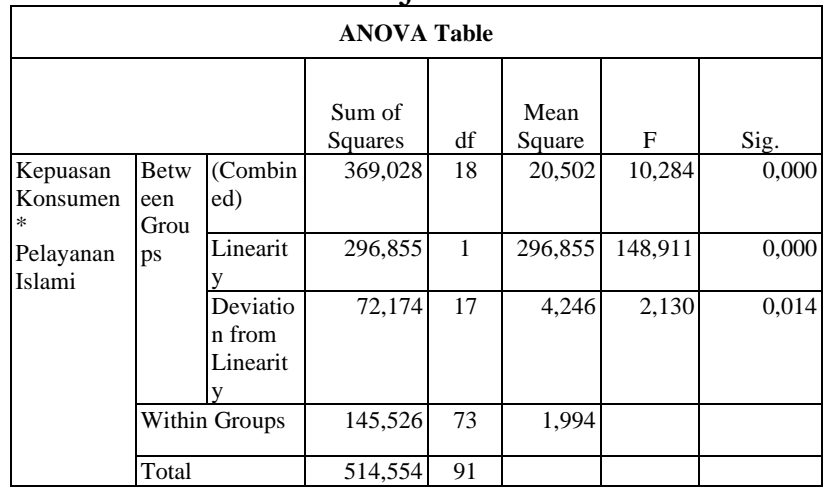

Sumber: diolah oleh SPSS versi 25, 2019.

Berdasarkan tabel 3.6 linearitas diketahui nilai signifikansi linearity diperoleh hasil $0,000<0,05$ sehingga dapat disimpulkan terdapat hubungan yang linear antara variabel Pelayanan Islami (X) dengan variabel Kepuasan Konsumen (Y).

\section{Uji Hipotesis}

\section{Uji Parsial (t)}

Uji parsial (t) digunakan untuk mengetahui bahwa variabel independen secara parsial mempunyai pengaruh yang signifikan terhadap variabel dependen. Pengambilan keputusan berdasarkan pada tingkat signifikansi sebesar $5 \%$ atau 0,05. Adapun hipotesis yang digunakan adalah sebagai berikut:

EKSISBANK (Ekonomi Syariah dan Bisnis Perbankan), Volume 4, Nomor 2, Desember 2020 http://journal.sties-purwakarta.ac.id/index.php/EKSISBANK/ 
Ha: terdapat pengaruh yang positif dan signifikan antara pelayanan Islami dengan kepuasan konsumen.

H0: tidak terdapat pengaruh yang positif dan signifikan antara pelayanan Islami dengan kepuasan konsumen.

Penarikan kesimpulan dilakukan berdasarkan pengujian hipotesis dengan kriteria yang telah ditetapkan. Adapun kriteria yang digunakan untuk penerimaan dan penolakan hipotesis nol (Ho) yaitu jika thitung> ttabel, maka $\mathrm{H} 0$ ditolak dan Ha diterima. Jika thitung < ttabel, maka HO diterima dan Ha ditolak.

2. Analisis Koefisien Determinasi(R2)

Uji koefisien determinasi (R2) digunakan untuk mengetahui persentasi pengaruh variabel independen terhadap variabel dependen. Intinya mengukur seberapa jauh kemampuan model dalam menerangkan variasi dari variabel dependen. Nilai koefesien determinasi adalah antara nol atau satu. Nilai R2 yang kecil berarti kemampuan variabelvariabel independen dalam menjelaskan variasi variabel dependen amat terbatas. Dan sebaliknya jika nilai yang mendekati 1 berarti variabel-variabel independen memberikan hampir semua informasi yang dibutuhkan untuk memprediksi variabel-variabel dependen (Melasari \& Handayani, 2018).

3. Analisis Regresi Linier Sederhana

Analisis regresi linier sederhana digunakan untuk mengukur besarnya pengaruh variabel bebas terhadap variabel terikat. Persamaan regresi linier sederhana untuk penelitian ini dituliskan dalam rumus (Sugiyono, 2015): Y $=\mathrm{a}+\mathrm{bx}$

Keterangan :

Y : Variabel Terikat (Kepuasan Konsumen)

$\mathrm{X}$ : Variabel Bebas (Pelayanan Islami)

a : Konstanta

b : Koefisien Regresi Variabel Independen, yang menunjukkan angka peningkatan ataupun penurunan variabel independen yang didasarkan pada perubahan variabel independen. Bila (+) arah garis naik, dan bila (-) maka arah garis turun.

\section{HASIL DAN PEMBAHASAN \\ A. Karakteristik Responden}

Karakteristik responden yang dibahas dalam penelitian ini bertujuan untuk menggambarkan keadaan atau kondisi responden yang dapat memberi informasi. Adapun karakteristik responden terdiri dari jenis kelamin, usia, pendidikan, pekerjaan dan status konsumen (sebagai anggota atau bukan anggota). Sampel yang dijadikan responden dalam penelitian ini adalah konsumen di 212 Mart Purwakarta yang berjumlah 92 orang. Berdasarkan hasil penelitian terhadap 92 responden melalui kuesioner yaitu sebagai berikut:

\section{Distribusi Karakteristik Responden}

\section{a.Distribusi Karakteristik Responden} Berdasarkan Jenis Kelamin

Hasil analisis mengenai responden berdasarkan jenis kelamin dapat dilihat pada diagram dibawah ini:

Diagram 4.1

Distribusi Berdasarkan Jenis Kelamin

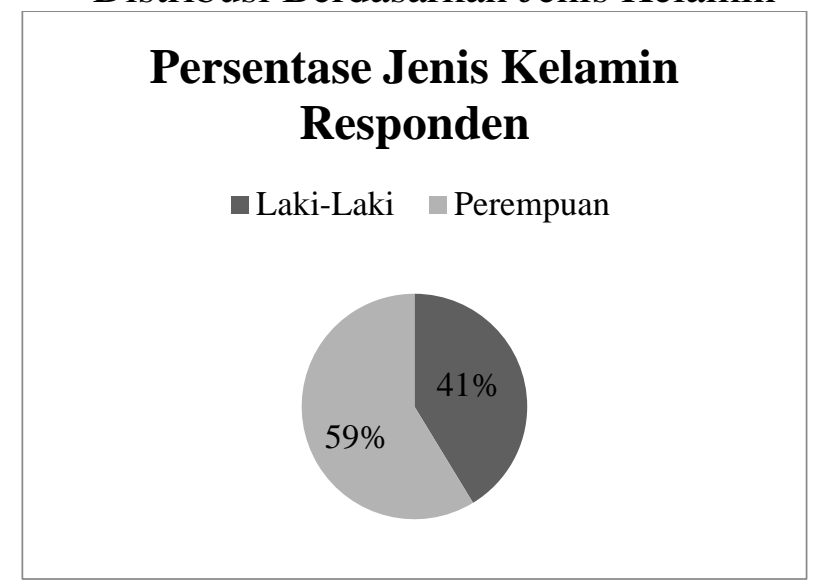

Sumber diolah oleh peneliti, 2019.

Berdasarkan diagram 4.1 menunjukkan bahwa responden yang berjenis kelamin lakilaki berjumlah 38 orang dengan persentase $41 \%$ dan responden berjenis kelamin perempuan 
berjumlah 54 orang dengan persentase $59 \%$ sehingga dapat disimpulkan bahwa konsumen 212 Mart Purwakarta yang dijadikan responden mayoritas berjenis kelamin perempuan.

\section{b.Distribusi Karakteristik Responden Berdasarkan Usia}

Hasil analisis mengenai responden berdasarkan usia dapat dilihat pada diagram dibawah ini:

Diagram 4.2

Distribusi Berdasarkan Us

Persentase Usia Responden
Kurang dari 20 tahun $\backsim 21-30$ tahun
$\square 31-40$ tahun $\quad$ - $41-50$ tahun
Lebih dari 50 tahun
$14 \%$
$11 \%$

Sumber diolah oleh peneliti, 2019.

Berdasarkan diagram 4.2 menunjukkan bahwa responden yang berusia kurang dari 20 tahun sebanyak 10 dengan persentase $11 \%$, sedangkan yang berusia 21-30 tahun sebanyak 34 orang atau dengan persentase $37 \%$, usia 31-40 tahun sebanyak 18 orang atau dengan persentase 20\%, usia 41-50 tahun sebanyak 17 orang atau dengan persentase $18 \%$, dan usia lebih dari 50 tahun sebanyak 13 orang atau dengan persentase 14\%. Dari data tersebut dapat disimpulkan bahwa konsumen 212 Mart Purwakarta mayoritas berusia 21- 30 tahun.

\section{c. Distribusi Karakteristik Responden Berdasarkan Pendidikan}

Hasil analisis mengenai responden berdasarkan pendidikan dapat dilihat pada diagram dibawah ini:
Diagram 4.3

Distribusi Berdasarkan Pendidikan

\begin{tabular}{l} 
Persentase Pendidikan Responden \\
$\square$ SD/sederajat $\quad \square$ SMP/sederajat \\
$\square$ SMA/sederajat $\quad$ Perguruan Tinggi \\
\hline $5 \%$
\end{tabular}

Sumber diolah oleh peneliti, 2019.

Berdasarkan diagram 4.3 menunjukkan bahwa pendidikan responden adalah $\mathrm{SD} /$ sederajat sebanyak 6 orang atau dengan persentase 7\%, SMP/sederajat sebanyak 15 orang atau dengan persentase $16 \%$, SMA/sederajat sebanyak 51 orang atau dengan persentase 55\%, Perguruan Tinggi 20 orang atau dengan persentase $22 \%$. Dari data diatas dapat disimpulkan bahwa sebagian besar pendidikan konsumen di 212 Mart Purwakarta adalah SMA/sederajat.

\section{d.Distribusi Karakteristik Responden Berdasarkan Pekerjaan}

Hasil analisis mengenai responden berdasarkan pekerjaan dapat dilihat pada diagram dibawah ini:

Diagram 4.4

Distribusi Berdasarkan Pekerjaan

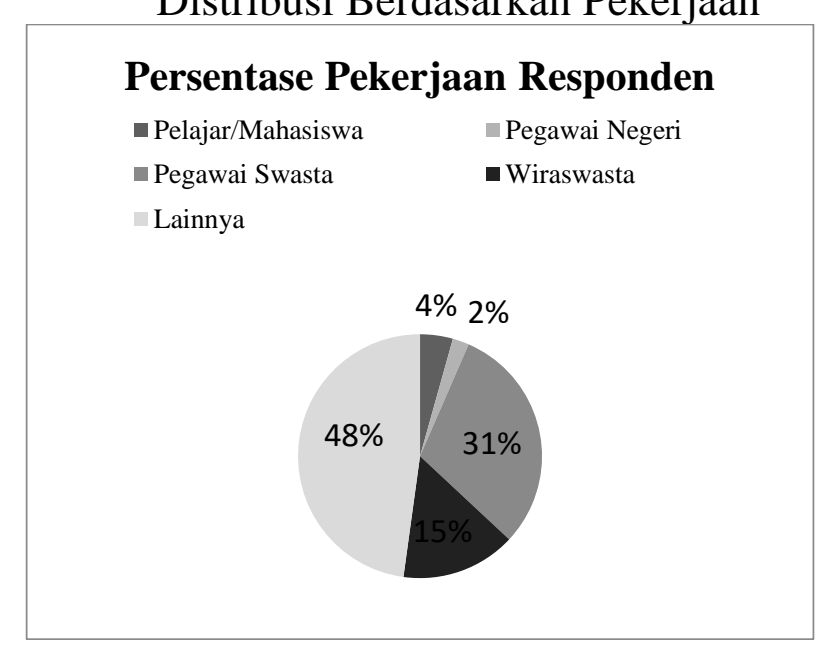

Sumber diolah oleh peneliti, 2019.

EKSISBANK (Ekonomi Syariah dan Bisnis Perbankan), Volume 4, Nomor 2, Desember 2020 
Berdasarkan diagram 4.4 menunjukkan bahwa konsumen di 212 Mart Purwakarta yang memiliki pekerjaan sebagai mahasiswa atau pelajar sebanyak 4 orang atau dengan persentase $4 \%$, pegawai negeri sebanyak 2 orang atau dengan persentase $2 \%$, pegawai swasta sebanyak 28 orang atau dengan persentase $31 \%$, pekerjaan wiraswasta sebanyak 14 orang atau dengan persentase $15 \%$, dan yang tersisa pekerjaan lainya sebanyak 44 orang atau dengan persentase 48\%. Dari data diatas dapat disimpulkan bahwa konsumen 212 Mart Purwakarta sebagian besar adalah yang mempunyai pekerjaan lain-lain, seperti ibu rumah tangga.

\section{e. Distribusi Karakteristik Responden \\ Berdasarkan Status Konsumen}

Hasil analisis mengenai responden berdasarkan status konsumen dapat dilihat pada diagram dibawah ini:

\section{Diagram 4.5}

Distribusi Berdasarkan StatusKonsumen

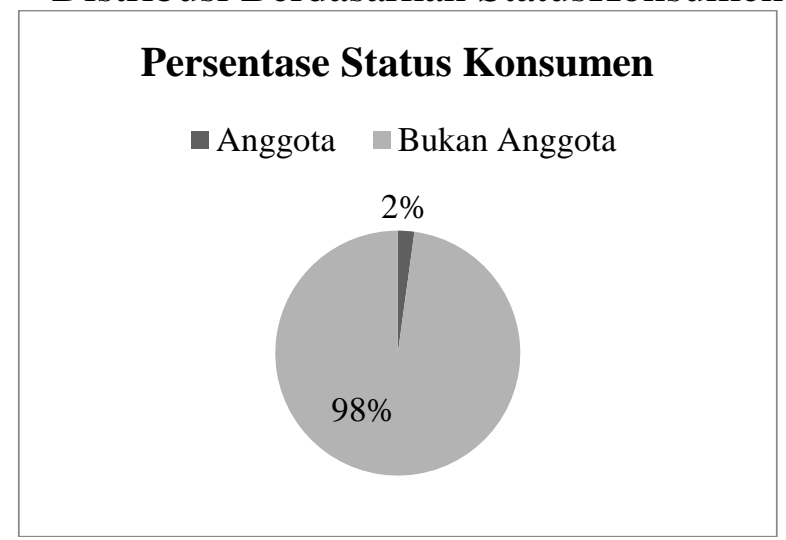

Sumber diolah oleh peneliti, 2019.

Berdasarkan diagram 4.5 menunjukkan bahwa jumlah responden yang berstatus sebagai anggota di 212 Mart Purwakarta berjumlah 2 orang atau dengan persentase $2 \%$ sedangkan yang berstatus bukan anggota berjumlah 90 orang atau dengan persentase 98\%. Dari data diatas dapat disimpulkan bahwa konsumen 212 Mart Purwakarta yang dijadikan responden yaitu mayoritas bukan anggota.

\section{B. Hasil Uji Statistik}

1. Uji Parsial (t)

Tabel 4.1

Hasil Uji Parsial (t)

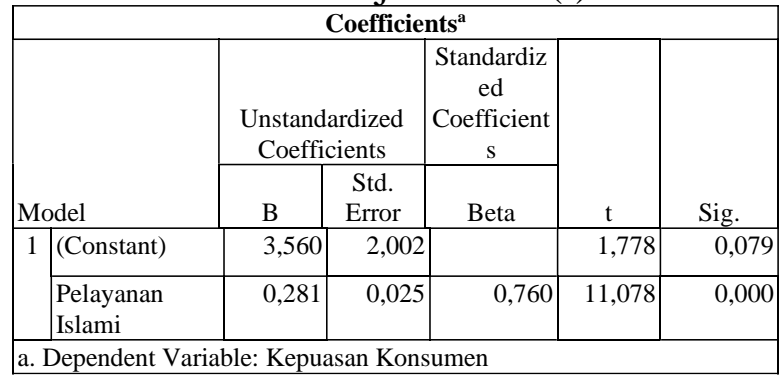

Sumber: diolah oleh SPSS versi 25, 2019.

Berdasarkan tabel 4.1 hasil uji parsial (t) dapat ditarik kesimpulan sebagai berikut:

1) Nilai signifikansi dari tabel Coefficients diperoleh nilai signifikansi sebesar 0,000 $<$ 0,05 maka dapat disimpulkan bahwa variabel pelayanan Islami (X) berpengaruh secara signifikan terhadap variabel kepuasan konsumen (Y).

2) 2. Berdasarkan nilai t, diketahui nilai thitung 11,078 > ttabel 2,011 , sehingga dapat disimpulkan bahwa variabel pelayanan Islami $(\mathrm{X})$ berpengaruh secara signifikan terhadap variabel kepuasan konsumen (Y).

\section{Uji Koefisien Determinasi}

Tabel 4.2

Hasil Uji Koefisien Determinasi

\begin{tabular}{|c|c|c|c|c}
\hline \multicolumn{5}{|c}{ Model Summary } \\
\hline Model & $\mathrm{R}$ & $\begin{array}{c}\mathrm{R} \\
\text { Square }\end{array}$ & $\begin{array}{c}\text { Adjusted } \\
\text { R Square }\end{array}$ & $\begin{array}{c}\text { Std. Error of } \\
\text { the Estimate }\end{array}$ \\
\hline 1 &, $760^{\mathrm{a}}$ & 0,577 & 0,572 & 1,55528 \\
\hline
\end{tabular}

Sumber: diolah oleh SPSS versi 25, 2019.

Berdasarkan tabel 4.2 menjelaskan tentang korelasi/hubungan (R) yaitu sebesar 0,760. Dari output tabel 3.8 diperoleh koefisien determinasi (R Square) sebesar 0,577 yang mengandung pengertian bahwa pengaruh variabel bebas (Pelayanan Islami) terhadap variabel terikat (Kepuasan Konsumen) sebesar 57,7\%. 


\section{Analisis Regresi Sederhana}

Analisis regresi sederhana digunakan untuk menguji pengaruh satu variabel bebas terhadap variabel terikat.

Berdasarkan hasil uji parsial (t) diketahui bahwa nilai Constant (a) sebesar 3,560 sedangkan nilai pelayanan Islami (b/koefisien regresi) sebesar 0,281 sehingga persamaan regresinya dapat ditulis :

$$
\begin{aligned}
& Y=a+b X \\
& Y=3,560+0,281 X
\end{aligned}
$$

Keterangan:

1) Konstanta sebesar 3,560, mengandung arti bahwa nilai konsisten variabel kepuasan konsumen adalah sebesar 3,560.

2) Koefisien regresi $X$ sebesar 0,281 menyatakan bahwa setiap penambahan $1 \%$ nilai pelayanan Islami, maka nilai kepuasan konsumen bertambah sebesar 0,281 . Koefisien regresi tersebut bernilai positif sehingga dapat dikatakan bahwa arah pengaruh variabel $\mathrm{X}$ terhadap $\mathrm{Y}$ adalah positif.

\section{Pengaruh Pelayanan Islam (X) terhadap Kepuasan Konsumen (Y)}

Berdasarkan kuesioner yang telah diisi oleh responden berjumlah 92 orang dan telah diuji dengan menggunakan SPSS versi 25 menunjukkan bahwa :

Hasil uji validitas variabel $\mathrm{X}$ (Pelayanan Islami) dan Y (Kepuasan Konsumen) dinyatakan valid karena seluruh item soal memiliki $r>0,207$ dan signifikansi $<0.05$.

Uji reliabilitas dapat dilakukan secara bersama-sama terhadap seluruh butir pertanyaan. Nilai $r$ tabel untuk alpha cronbach dengan signifikansi 0,05 untuk penelitian ini adalah 0,60.

Berdasarkan hasil uji reliabilitas memperoleh $\mathrm{r}$ hitung dari variabel pelayanan Islami $(0,922)$ dan kepuasan konsumen $(0,797)$ sehingga dapat simpulkan seluruh variabel tersebut reliabel.
Hasil uji normalitas menggunakan uji kosmogorov-smirnov diperoleh nilai signifikansi variabel $\mathrm{X}$ (pelayanan Islami) sebesar 0,099>0,05 sehingga dapat disimpulkan nilai residual berdistribusi normal.

Hasil uji linearitas diperoleh nilai signifikansi linearity $0,000<0,05$ sehingga dapat disimpulkan terdapat hubungan yang linear antara variabel Pelayanan Islami (X) dengan variabel Kepuasan Konsumen (Y).

Hasil uji koefisien determinasi menunjukkan pengaruh pelayanan Islami terhadap kepuasan konsumen di 212 Mart Purwakarta sebesar 57,7\%. Hal ini terbukti nilai $\mathrm{R}$ Square adalah 0,577 yang $\%$ menunjukkan bahwa variabel $\mathrm{Y}$ dipengaruhi oleh variabel X sebesar 57,7\%.

Hasil uji parsial (t) variabel pelayanan Islami memperoleh thitung 11,078 > ttabel 2,011 dengan nilai signifikansi $0,000<0,05$ sehingga dapat diambil kesimpulan bahwa variabel pelayanan Islami $(\mathrm{X})$ berpengaruh secara positif dan signifikan terhadap variabel kepuasan konsumen (Y).

Berdasarkan output uji t, persamaan regresi sederhana pada penelitian ini sebagai berikut : Konstanta sebesar 3,560, mengandung arti bahwa nilai konsisten variabel kepuasan konsumen adalah sebesar 3,560. Koefisien regresi X sebesar 0,281 menyatakan bahwa setiap penambahan $1 \%$ nilai pelayanan Islami, maka nilai kepuasan konsumen bertambah sebesar 0,281. Koefisien regresi tersebut bernilai positif sehingga dapat dikatakan bahwa arah pengaruh variabel $\mathrm{X}$ terhadap $\mathrm{Y}$ adalah positif

\section{KESIMPULAN}

Berdasarkan hasil uji statistik menggunakan software SPSS versi 25 menunjukkan bahwa pelayanan Islami memberikan pengaruh secara positif dan signifikan terhadap kepuasan konsumen di 
212 Mart Purwakarta sebesar 57,7\% dengan nilai signifikansi $0,000<0,05$ dengan koefisien regresi $\mathrm{X}$ sebesar 0,281 yang artinya bahwa setiap penambahan $1 \%$ nilai pelayanan Islami, maka nilai kepuasan konsumen bertambah sebesar 0,281 sedangkan sisanya sebesar $42,3 \%$ dipengaruhi oleh variabel lain diluar variabel yang digunakan dalam penelitian ini. Penelitian ini memperkuat Haisl penelitian terdahulu yang dilakukan oleh hadian dan Gunawarman (Gunawarman \& Ratnasari, 2020; Hadian \& Rahmat, 2019)

\section{DAFTAR PUSTAKA}

Arifin, J. (2007). Fiqih Perlindungan Konsumen. Rasail.

Azis, A. (2013). Etika Bisnis Perspektif Islam. Alfabeta.

Dayu, W. (2019). Analisis Keterkaitan Kualitas Pelayanan Terhadap Consumer Satisfaction Minimarket 212 Di Kota Medan. In Al - Muamalat: Jurnal Hukum dan Ekonomi Syariah (Vol. 4, Issue I). https://doi.org/10.32505/MUAMALAT. V4I01.954

Destarini, F., \& Prambudi, B. (2020). Pengaruh Produk Dan Harga Terhadap Keputusan Pembelian Pada Konsumen 212 Mart Condet Batu Ampar. Jurnal Ekobis : Ekonomi Bisnis \& Manajemen, 10(1), $58-66$.

https://doi.org/10.37932/j.e.v10i1.27

Gunawarman, I. P., \& Ratnasari, R. T. (2020).

Faktor Yang Mempengaruhi Konsumen Untuk Memilih 212 Mart Surabaya Sebagai Tempat Untuk Berbelanja. Jurnal Ekonomi Syariah Teori Dan Terapan, 7(1), 50-69. https://doi.org/10.20473/vol7iss20201pp 50-69

Hadian, A., \& Rahmat, M. (2019). Pengaruh Kualitas Pelayanan Retail Terhadap
Kepuasan Konsumen Pada Swalayan Mart 212 Di Kota Medan. ECOBISMA (JURNAL EKONOMI, BISNIS DAN MANAJEMEN), 6(2), 129-136. https://doi.org/10.36987/ecobi.v6i2.12

Hartati, N. (2019). Wawancara Tentang Pelayanan Konsumen di 212 Mart Purwakarta. Owner/Kepala Toko 212 Mart Purwakarta.

Hartati, R. (2019). Pengaruh Kepuasan Dan Kualitas Pelayanan Karyawan 212 Mart Terhadap Loyalitas Konsumen (Studi Kasus Pada Konsumen 212 Mart Mutiara, Cibarusah - Bekasi). Jurnal Al-Fatih Global Mulia, 1(2), 2019. https://jurnalglobalmulia.or.id/index.php /alfatih/article/view/10

Hilmi, R. (2020). Pengaruh Bauran Pemasaran Terhadap Keputusan Pembelian Pada 212 Mart Banjarmasin. Jurnal Mitra Manajemen, 4(4), 550-565. http://www.ejurnalmitramanajemen.com/index.php/j $\mathrm{mm} /$ article/view/363

Kasmir. (2005). Etika Customer Service. Raja Grafindo Persada.

Kotler, P., \& Keller, K. L. (2009). Manajemen Pemasaran (Jilid 2 Ed). Erlangga.

Matondang, S. P. S. B., \& Kesuma, T. M. (2020). Pengaruh Store Atmosphere Terhadap Keputusan Pembelian Konsumen Muslim Di 212 Mart Banda Aceh. Jurnal Ilmiah Mahasiswa Ekonomi Manajemen, 5(3), 469-487. http:jim.unsyiah.ac.id/ekm

Melasari, R., \& Handayani, F. (2018). Pengaruh Desentralisasi Dan Sistem Akuntansi Manajemen Terhadap Kinerja Manajerial Pada PT. Sinar Mas Kempas Jaya. Jurnal Akuntasi Dan Keuangan, $7(2), 1-15$. 
Moenir. (1996). Manajemen Pelayanan Umum di Indonesia. Bumi Aksara.

Rahwani, R., \& Murtani, A. (2020). Analisis Pengaruh Gaya Kepemimpinan Terhadap Kepuasan Kerja,Kinerja Dan Loyalitas Karyawan 212 Mart Kota Medan. In Jurnal Mahasiswa Fakultas Ekonomi dan Bisnis (Vol. 1, Issue 1). http://ejournal.potensiutama.ac.id/ojs/index.php/FEB/article/vi ew/750

Ramdhani, R., Rodiyah, R., \& Mardiyansyah, M. (2020). Brand Image 212 Mart Dalam Meningkatkan Penjualan Produk Perspektif Manajemen Dakwah. In DAWUH : Islamic Communication Journal (Vol. 1, Issue 2). https://www.siducat.org/index.php/dawu $\mathrm{h} /$ article/view/70

Sugiyono. (2015). Metode Penelitian
Kuantitatif, Kualitatif dan $R \& D$. Alfabeta.

Sujarweni, V. W. (2015). Statistik untuk Bisnis dan Ekonomi. Pustaka.

Sula, M. S., \& Kartajaya, H. (2006). Syariah Marketing. Mizan.

Susanto, H. (2008). Hak-Hak Konsumen yang Dirugikan. Transmedia Pustaka.

Tjiptono, F., \& Chandra, G. (2004). Service Quality Satisfaction. Andi.

Wati, I., \& Murtani, A. (2020). Pengaruh Motivasi, Lingkungan Kerja Dan Kinerja Terhadap Kepuasan Kerja Karyawan (Studi Kasus Pada 212 Mart Medan). In Jurnal Mahasiswa Fakultas Ekonomi dan Bisnis (Vol. 1, Issue 1). http://ejournal.potensiutama.ac.id/ojs/index.php/FEB/article/vi ew/773 